
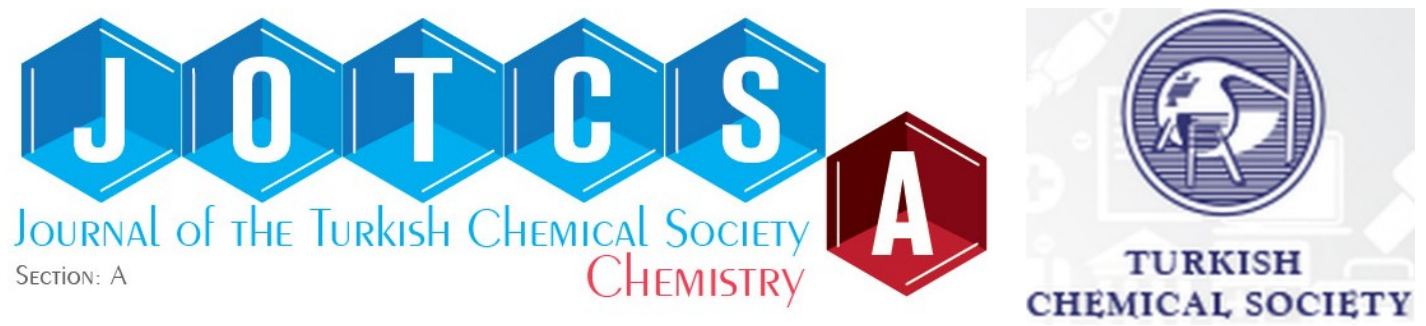

\title{
Kinetic and Thermodynamic Study on Adsorption of Cadmium from Aqueous Solutions Using Natural Clay
}

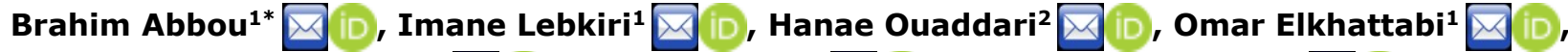

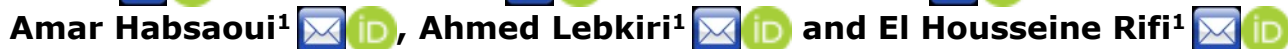

${ }^{1}$ Laboratory of Advanced Materials and Process Engineering, Chemistry Department, Ibn Tofail University, B.P. 133, Kenitra, Morocco.

'Laboratory of Materials, Membranes and Environment, Faculty of Sciences and Technologies of Mohammedia, Hassan II University, Casablanca, Morocco.

\begin{abstract}
Heavy metal pollution poses a great risk for the environment and the human health. Cadmium is among the most common pollutants found in wastewater, known for its great toxicity even in small doses. This work aims to study the removal of cadmium using natural Moroccan clay (MC). The clay was characterized using X-ray diffraction, X-ray fluorescence, Fourier transform infrared spectroscopy, BET, and SEM. The effects of several experimental parameters on the clay adsorption capacity towards cadmium ions, such as MC dose, initial concentration and contact time, initial $\mathrm{pH}$, and temperature were studied. The kinetic models Pseudo-first order, Pseudo-second order, and Elovich are evaluated to identify the adsorption process. The adsorption mechanism was determined by the use of the adsorption isotherms: Langmuir, Freundlich, and Temkin model. The results show that the heavy metal retention obeys the Pseudo-second order $\left(R^{2} \geq 0.99\right)$. The Langmuir isotherm model provided the best fit $\left(R^{2} \geq 0.99\right)$ to the experimental data for the adsorption of $\mathrm{Cd}(\mathrm{II})$ by $\mathrm{MC}$ as compared to the Freundlich and Temkin model. The maximum monolayer adsorption capacity of $\mathrm{Cd}(\mathrm{II})$, using the Langmuir model equation, is equal to $5.25 \mathrm{mg} / \mathrm{g}$. The adsorption is a spontaneous and an endothermic process characterized by a disorder of the medium.
\end{abstract}

Keywords: Clay, heavy metal, cadmium, adsorption, isotherm.

Submitted: February 17, 2021. Accepted: May 11, 2021.

Cite this: Abbou B, Lebkiri I, Ouaddari H, Elkhattabi O, Habsaoui A, Lebkiri A, et al. Kinetic and Thermodynamic Study on Adsorption of Cadmium from Aqueous Solutions Using Natural Clay. JOTCSA. $2021 ; 8(2): 677-92$.

DOI: https://doi.org/10.18596/jotcsa.882016.

*Corresponding author. E-mail: abbou.brahim@gmail.com.

\section{INTRODUCTION}

Increased urbanization and industrialization activities have led to global economic development, which has significantly contributed to human wellbeing, but this had a negative effect on the environment. Indeed, the uncontrollable control of waste and wastewater discharges creates a series of environmental problems, making it difficult to access adequate quality water for human consumption (1). Heavy metals pollution, in particular, is an environmental problem of global interest (2). They are considered one of the most dangerous inorganic contaminants among many others released into the environment. The reason behind this is their persistence in nature and their toxicity even at a very low concentration (3).

The protection of Aquatic Resources and the environment and the elimination of heavy metals are always a great challenge. The accumulation of this toxic waste comes mainly from human activities 
such as agriculture, mining, and industry. Currently, they are of great concern because of their toxicity to ecosystems and their harmful effects on human health. Cadmium is considered to be dangerous micropollutants (4), the toxicity caused by this metal is considered to be high even to the state of traces (5).

Numerous studies have made it possible to develop various industrial effluent treatment processes to reduce these contaminants quantity in aquatic environments. These studies include chemical precipitation processes, coagulation/flocculation, ion exchange, membrane processes, and adsorption (614).

The adsorption process has proven to be highly efficient and cost-effective for removing organic substances (pesticides, dyes, phenolic compounds, etc.) and heavy metals (cadmium, lead, mercury, etc.). (7-11).

Moreover, the research and development of new low-cost, cost-effective, and efficient adsorbents for ecosystem treatment remains a great challenge. Natural adsorbents such as agricultural solid waste, algae, soils, and clays modified or not have shown promising profitability for trapping pollutants $(4,6,15,16)$. Recently clay minerals have received considerable attention as alternative adsorbent materials that are less expensive, abundant and have multifunctional properties depending on the type of clay (17). The main advantages of using these materials are due to their different characteristics, abundant availability, and low cost (18).

This work aims to enhance Moroccan natural clay's value in the retention of cadmium ions from synthetic aqueous solutions. The influence of adsorption conditions such as MC dose, initial concentration and contact time, initial $\mathrm{pH}$, and temperature were investigated. To better understand the nature of the reaction mechanisms involved in the adsorption phenomenon, the linear shapes of different kinetic and isothermal models were calculated and evaluated.

\section{EXPERIMENTAL SECTION}

\section{Characterization techniques}

The X-ray diffraction analyses were carried out using a PANalytical X'Pert PRO Plus diffractometer, using $\mathrm{Cu}-\mathrm{Ka}$ radiation $(\lambda=1.5406 \AA)$. The value of $2 \theta$ angle was scanned between 3 and $90^{\circ}$ range at a goniometer rate of $2 \theta=4 \% / \mathrm{min}$. The chemical composition of MC was determined with X-ray fluorescence using an Axios-Panalytical device. The analysis of the MC by Fourier Transform Infrared Spectroscopy was carried out by using a Vertex 70 spectrometer, the analysis was performed by scanning from $4000 \mathrm{~cm}^{-1}$ to $400 \mathrm{~cm}^{-1}$ with a resolution of $4 \mathrm{~cm}^{-1}$. BET Nitrogen adsorption measurements were obtained using a Micromeritics Flex 3 to obtain the specific surface area of MC. The morphology of $\mathrm{MC}$ was observed by Scanning electron microscopy (SEM) and Energy Dispersive Xray (EDAX) (FEI Company, Quanta 200).

\section{Adsorbent and Adsorbate}

The adsorbent used in this work is an unmodified clay collected from Marrakech region in southern Morocco. Before any use, the material was crushed and sieved; only the granulometry below $120 \mu \mathrm{m}$ is retained. The particles were then dried at $100{ }^{\circ} \mathrm{C}$ overnight and before any use.

The used stock solution of metal ions (Cd(II)) was prepared by dissolving a known amount of metal salt $\mathrm{Cd}\left(\mathrm{NO}_{3}\right)_{2} \quad 4 \mathrm{H}_{2} \mathrm{O} \quad(98 \%)$, purchased from Solvachim (Casablanca, Morocco), in distilled water. The desired working concentrations solution is prepared by diluting the stock solution.

\section{Adsorption Experiments}

The adsorption tests were conducted in the batch method under different experimental parameters, such as the adsorbent dose, initial concentration and contact time, $\mathrm{pH}$ of the solution, and temperature. After the adsorption process, MC was separated from the liquid phase using a $0.45 \mu \mathrm{m}$ membrane filter; the recovered filtrate was analyzed by Inductively Coupled Plasma Optical Emission Spectroscopy (ICP-OES). The data obtained from the adsorption experiments are used to calculate the adsorption efficiency and capacity by the following equations:

$$
\begin{gathered}
R \%=\frac{\left(C_{0}-C_{r}\right)}{C_{0}} \times 100 \\
q_{(m g / g)}=\frac{\left(C_{0}-C_{r}\right)}{m} V
\end{gathered}
$$

Where $C_{0}(\mathrm{mg} / \mathrm{L})$ and $C_{r}(\mathrm{mg} / \mathrm{L})$ are respectively the initial and the residual concentration of adsorbate, $\mathrm{V}(\mathrm{L})$ is the solution volume, and $\mathrm{m}(\mathrm{g})$ is the adsorbent mass.

\section{RESULTS AND DISCUSSION}

\section{Characterization of the adsorbent \\ $X$-ray diffraction \\ X-ray diffraction was done to determine the mineralogical composition of MC. The obtained XRD patterns for MC are shown in Figure 1. According to the XRD pattern, our compound is not pure and contains a high quantity of quartz (JCPDS file No:}


01-085-0797; peaks around $4.26 \AA\left(20.81^{\circ} 2 \theta\right)$, $2,46 \AA\left(36.43^{\circ} 2 \theta\right), 2.28 \AA\left(39.45^{\circ} 2 \theta\right), 2.23 \AA$ $\left(40.38^{\circ} 2 \theta\right), 2.12 \AA\left(42.62^{\circ} 2 \theta\right), 1.98 \AA\left(45.90^{\circ}\right.$ $2 \theta), 1.82 \AA\left(50.11^{\circ} 2 \theta\right), 1.67 \AA\left(54.72^{\circ} 2 \theta\right)$, and $\left.\begin{array}{lll}1,66 \AA & \AA 5.24^{\circ} & 2 \theta\end{array}\right)$. X-ray diffraction analysis indicated that the clay's mineralogical composition is mainly composed of illite (JCPDS file No: 00-0011098), with the presence of a small amount of kaolinite (JCPDS file No: 01-083-0971) $7.24 \AA$
(12.5 20), albite (JCPDS file No: 01-084-0752) $1.45 \AA\left(64.06^{\circ} 2 \theta\right)$, and vermiculite (JCPDS file No: 01-076-0847) $4.46 \AA\left(19.81^{\circ} 2 \theta\right)$.

Illite was characterized by interreticular distances $(\AA)$ and $2 \theta$ position of the diffractometric reflects at $10.11,8.76^{\circ} ; 5.01,17.71^{\circ} ; 3.68,24.18^{\circ} ; 3.50$, $25.42^{\circ} ; 3.24,27.45^{\circ}$ and $3.20,27.86^{\circ}$.

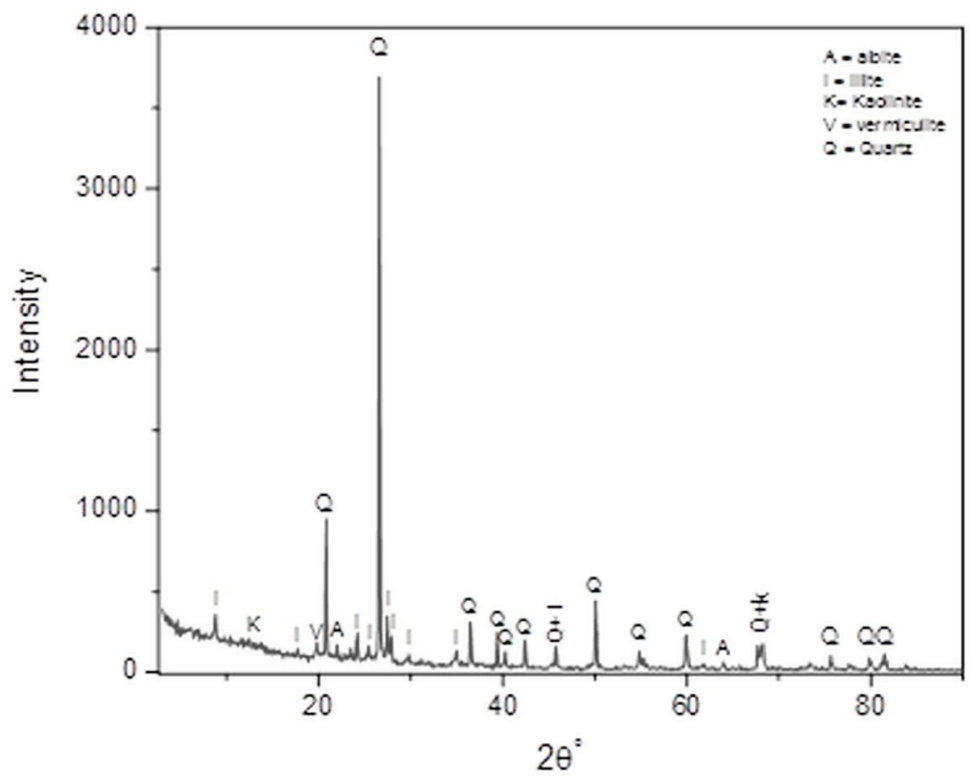

Figure 1: X-ray diffraction patterns of MC.

\section{$X$-ray fluorescence}

Elemental chemical analysis of the raw clay shown in Table 1 shows that silica and alumina are the predominant constituents. They are found in a $\mathrm{SiO}_{2} / \mathrm{Al}_{2} \mathrm{O}_{3}$ ratio equal to 3.64 , which is an indication of large proportion of quartz $(19,20)$. The low $\mathrm{CaO}$ content indicates a low amount of calcium carbonate (21). The loss on ignition (LOI) equal to $5.77 \%$ by mass. It is due to the decomposition of carbonates and dehydroxylation of clay minerals $(18,22)$.

\section{Fourier Transform Infrared Spectroscopy}

The FT-IR spectra (Figure 2) show a band that ranges between $3100-3700 \mathrm{~cm}^{-1}$ located at 3436 $\mathrm{cm}^{-1}$ due to the presence of the stretching vibrations of the internal $\mathrm{OH}$ groups of $\mathrm{H}_{2} \mathrm{O}$ molecule $(23,24)$, the two bands at $1637 \mathrm{~cm}^{-1}$ and $1381 \mathrm{~cm}^{-1}$ are attributed to the deformation of $\mathrm{H}_{2} \mathrm{O}(25,26)$. The bands located at 693, 776, $1005 \mathrm{~cm}^{-1}$, and 1031 $\mathrm{cm}^{-1}$ correspond to $\mathrm{Si}-\mathrm{O}$ stretching vibrations $(16,23,26-29)$. Intense peaks at $472 \mathrm{~cm}^{-1}$ and 533 $\mathrm{cm}^{-1}$ are attributable respectively to the deformation of $\mathrm{Si}-\mathrm{O}-\mathrm{Mg}$ and $\mathrm{Si}-\mathrm{O}-\mathrm{Al}(30)$. The band located at $912 \mathrm{~cm}^{-1}$ is attributed to the bending vibrations of the groups $\mathrm{Al}-\mathrm{Al}-\mathrm{OH}$ and $\mathrm{Al}-\mathrm{Mg}-\mathrm{OH}(31,32)$.

Table 1: Chemical composition of MC.

\begin{tabular}{ll}
\hline Elemental Composition & Weight \% \\
\hline $\mathrm{SiO}_{2}$ & 65.80 \\
$\mathrm{Al}_{2} \mathrm{O}_{3}$ & 18.10 \\
$\mathrm{Fe}_{2} \mathrm{O}_{3}$ & 3.56 \\
$\mathrm{~K}_{2} \mathrm{O}$ & 2.12 \\
$\mathrm{MgO}$ & 1.41 \\
$\mathrm{Na}{ }_{2} \mathrm{O}$ & 1.07 \\
$\mathrm{CaO}$ & 0.78 \\
$\mathrm{TiO}_{2}$ & 0.76 \\
$\mathrm{LoI}$ (Loss on ignition) & 5.77 \\
\hline
\end{tabular}




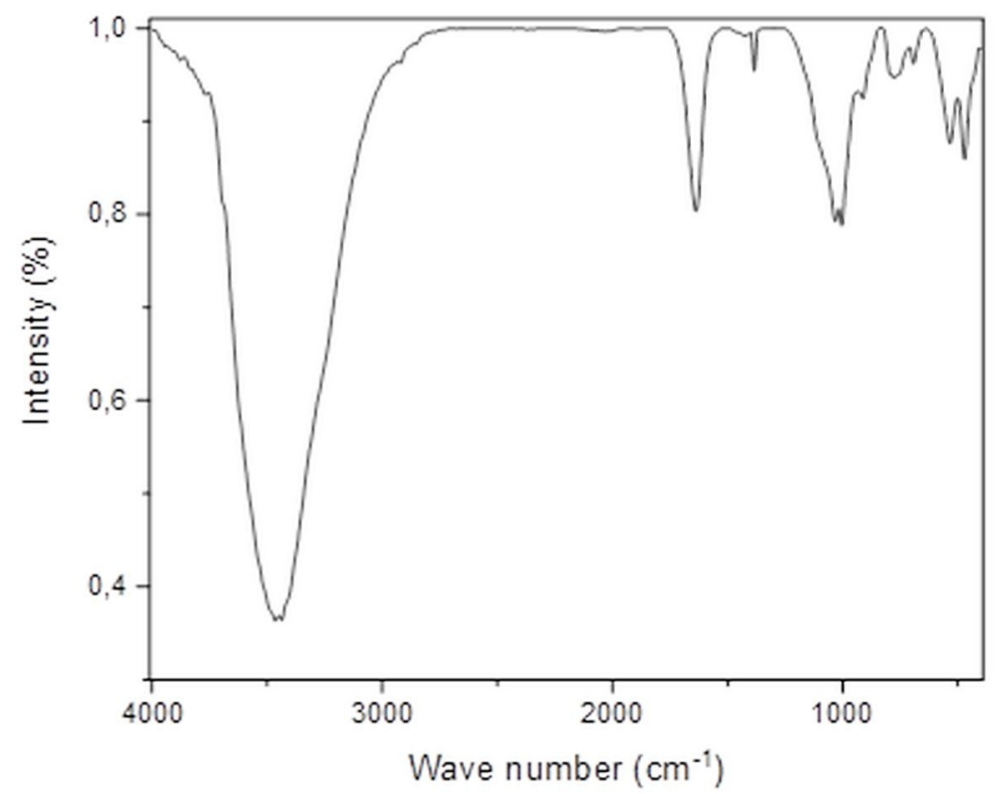

Figure 2: $F T-I R$ spectrum of $M C$.

Specific surface areas - BET

Figure 3 presents the nitrogen adsorptiondesorption isotherm at $77 \mathrm{~K}$ of $\mathrm{MC}$. The obtained isotherm is the type IV, with a hysteresis loop of type $\mathrm{H} 4$ and those according to the IUPAC classification (33). The specific surface area of $M C$ obtained by the BET method is $23.07 \mathrm{~m}^{2} / \mathrm{g}$.

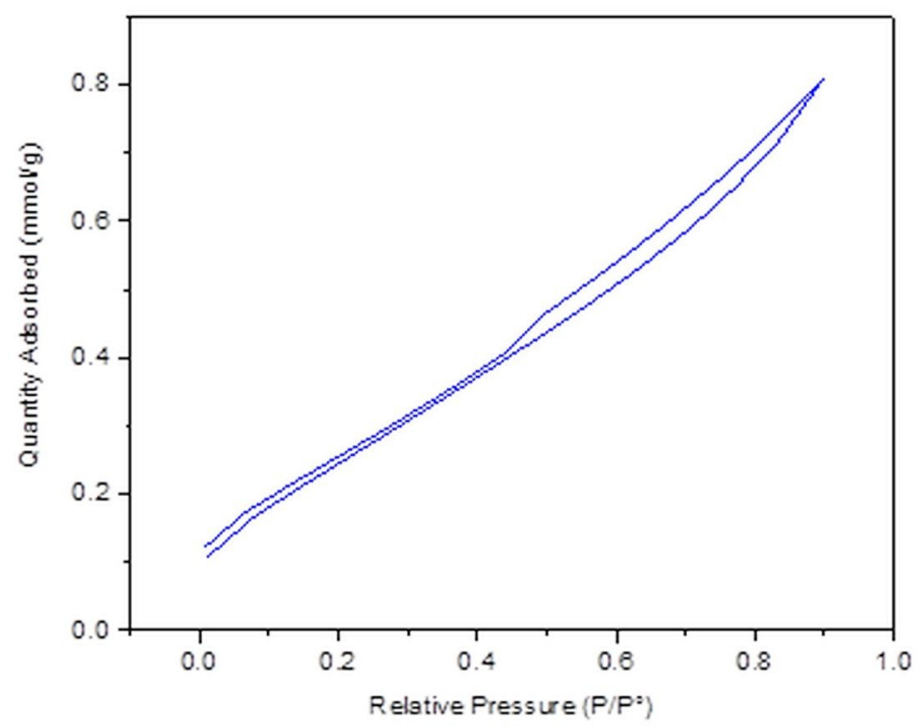

Figure 3: Adsorption-desorption isotherms of $\mathrm{N}_{2}$ at $77 \mathrm{~K}$ of $\mathrm{MC}$.

Scanning electron microscopy (SEM) and Energy Dispersive $X$-ray (EDAX)

The Scanning electron microscopy (SEM) for MC before and after adsorption are shown in Figure 4. The shape of the MC adsorbent particles have irregular structures (Figure 4a). The loaded MC showed some white particles on the surface of the mineral (Figure 4b), indicating the adsorption of cadmium on the surface of MC.
The elemental compositions of MC before and after adsorption were obtained with EDAX analysis, and the spectra were shown in Figure 5 . The results showed that $\mathrm{O}, \mathrm{Si}, \mathrm{Al}, \mathrm{Fe}$, and $\mathrm{K}$ were the major elements of $\mathrm{MC}$ clay, with the presence of small quantities of $\mathrm{C}, \mathrm{Ti}, \mathrm{Na}, \mathrm{Mg}$, and $\mathrm{Ca}$ (Figure $5 \mathrm{a}$ ). However, the additional peak corresponding to $\mathrm{Cd}$ element was observed in Figure 5b, which confirm the adsorption of $\mathrm{Cd}(\mathrm{II})$ onto $\mathrm{MC}$. 


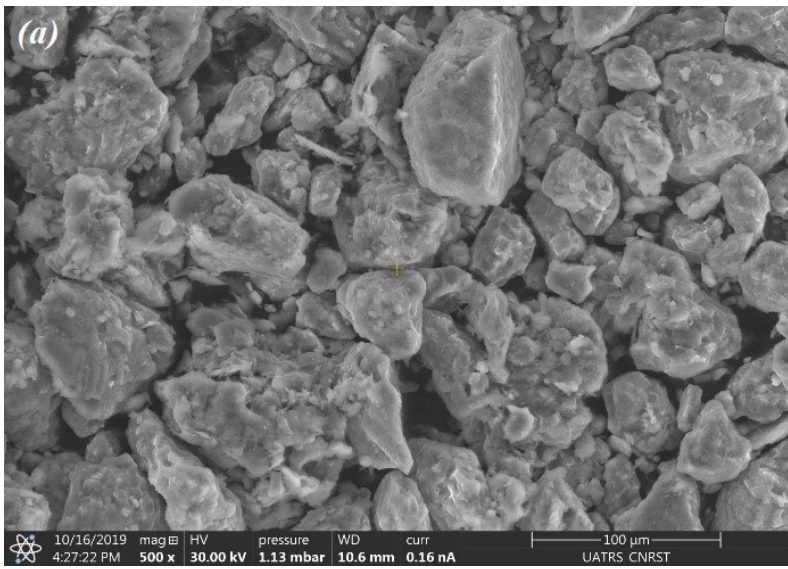

Figure 4: SEM of MC before

\section{Adsorption experiments}

Adsorbent mass effect

The mass effect on the adsorption of cadmium ions onto MC was conducted by contacting different masses of $\mathrm{MC}(0.1 \mathrm{~g}$ to $1.2 \mathrm{~g})$ with $0.1 \mathrm{~L}$ of $\mathrm{Cd}(\mathrm{II})$ $10 \mathrm{mg} / \mathrm{L}$ solution for 180 minutes. The results are illustrated in Figure 6. The efficiency of adsorption

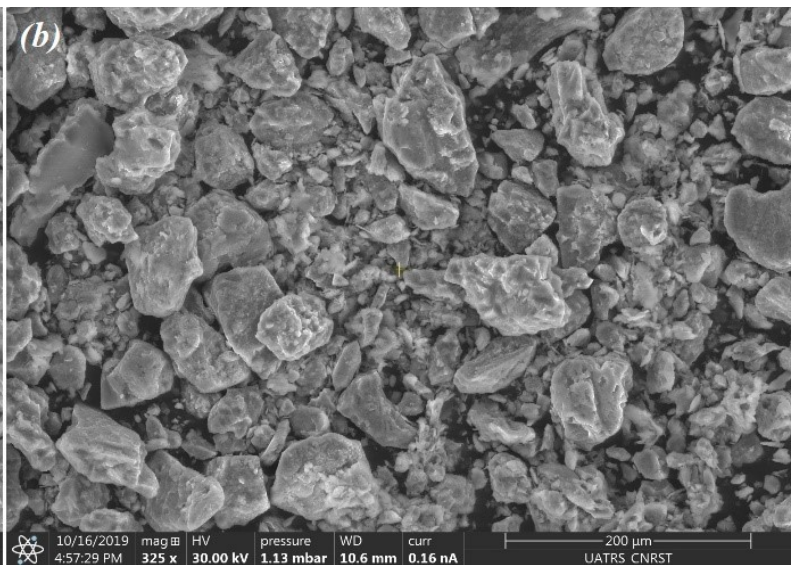

(a) and after (b) adsorption.

increases when MC mass increases in the solution. This is due to the increase in specific surface area and the adsorption active sites attributed to the increase in the adsorbent mass (34). From this result, a MC mass of $0.8 \mathrm{~g}$ will be used in all the following experiments.
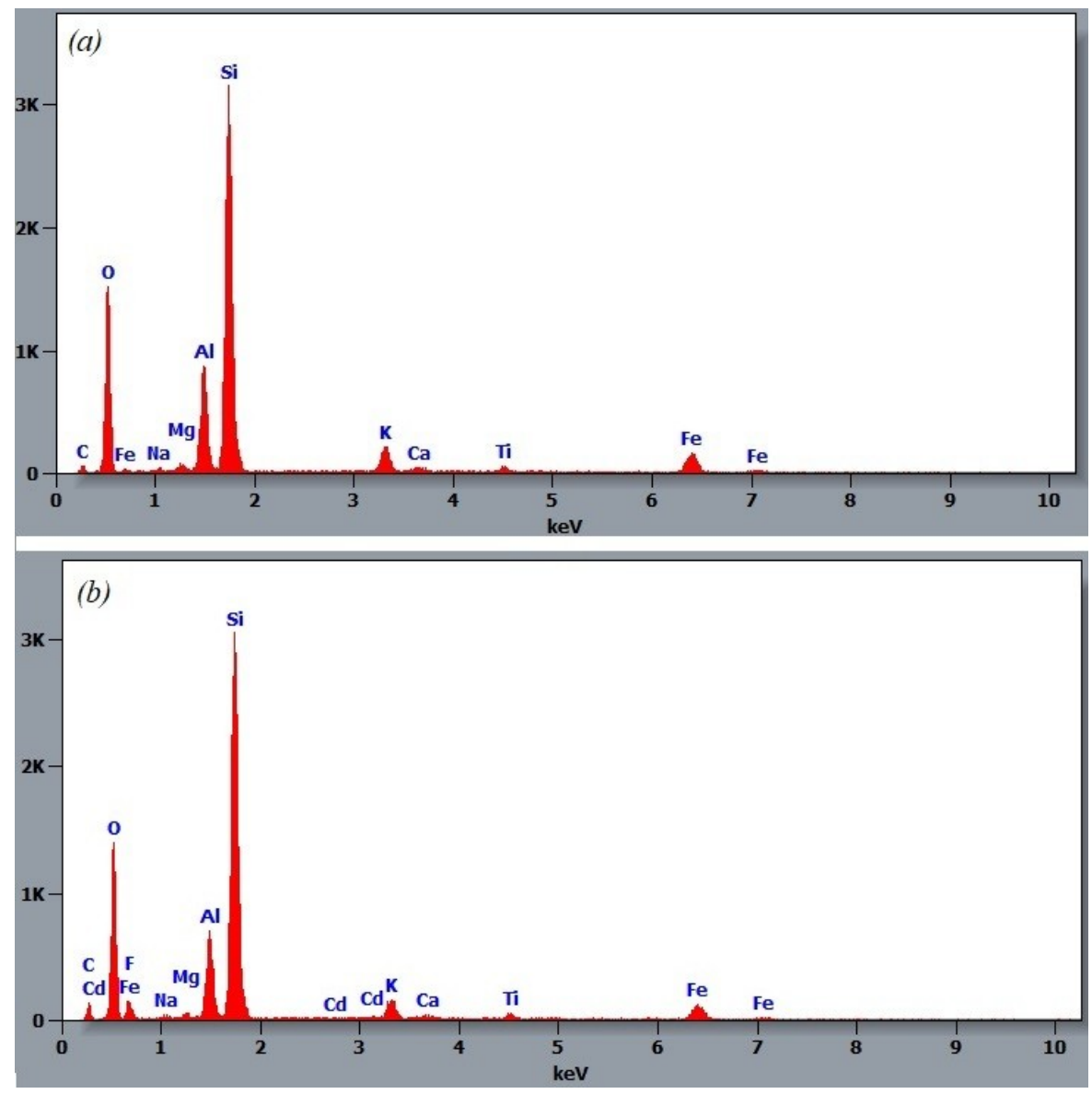

Figure 5: EDAX of MC before (a) and after (b) adsorption. 


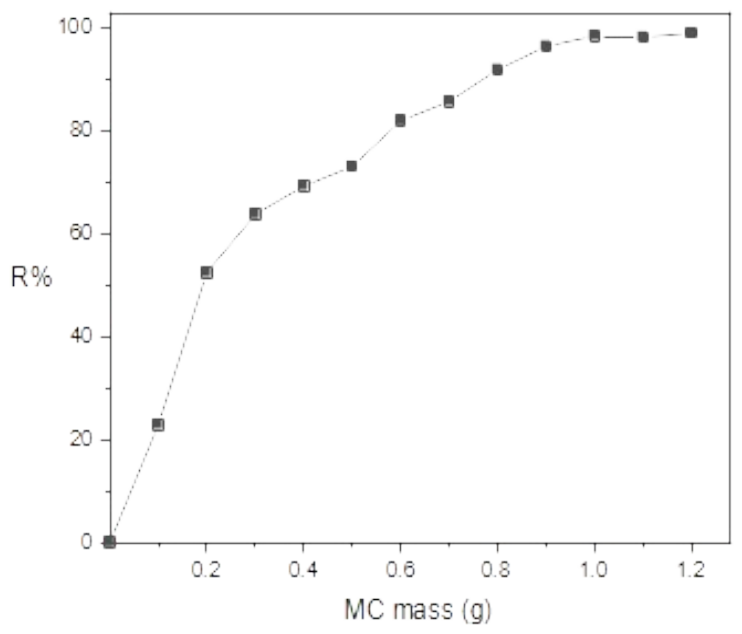

Figure 6: Evolution of heavy metal removal efficiency versus MC mass.

Initial concentration and contact time effect Contact time is a major parameter that controls the effectiveness of the adsorption phenomenon. Figure 7 shows the evolution of the adsorption capacity $q_{t}$ versus contact time for different cadmium concentrations $(10-200 \mathrm{mg} / \mathrm{L})$. It is found that the adsorption capacity $\left(\mathrm{q}_{\mathrm{t}}\right)$ increases with time in proportion as the concentration of the metal ion increases.

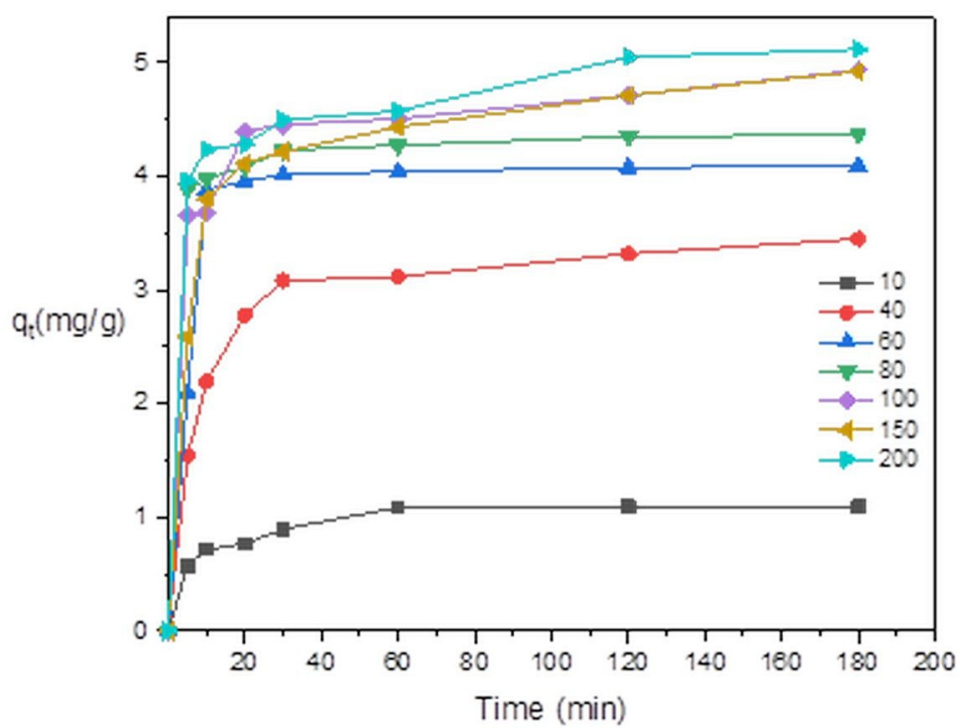

Figure 7: Time effect on the adsorption capacity of MC clay versus various initial concentrations of Cd(II).

Monitoring the initial concentration effect (Figure 8) shows that $\mathrm{q}_{\mathrm{e}}(\mathrm{mg} / \mathrm{g})$ increases with the accrues of the initial metal concentration, this increase is over when $\mathrm{MC}$ reaches its maximum adsorption capacity and becomes saturated with the adsorbed metal. In fact, at weak concentrations, the adsorption sites of $\mathrm{MC}$ are unoccupied and tend to fix more cadmium ions. In general, the amount of metal adsorbed increases from $1.09 \mathrm{mg} / \mathrm{g}$ to $5.12 \mathrm{mg} / \mathrm{g}$ with increasing initial concentration from $10 \mathrm{mg} / \mathrm{L}$ to 200 $\mathrm{mg} / \mathrm{L}$ of the metal solution and then reach a plateau corresponding to the adsorption sites saturation (35). The maximum adsorption capacity value obtained is $5.12 \mathrm{mg} \cdot \mathrm{g}^{-1}$. 


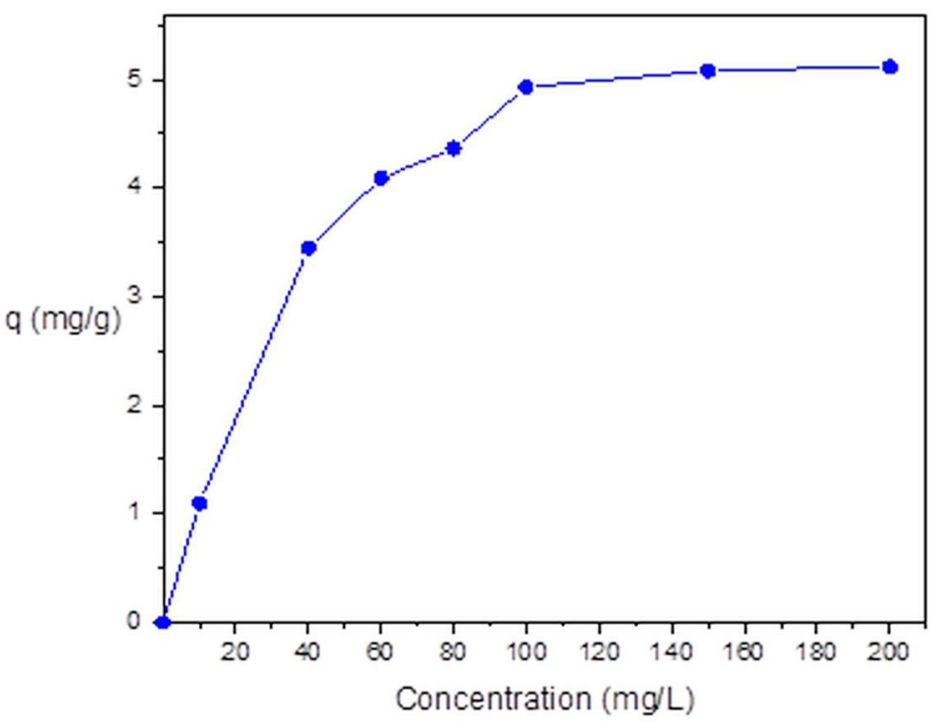

Figure 8: Adsorption capacity of MC.

Initial solution $\mathrm{pH}$ effect

To understand the influence of $\mathrm{pH}$ on $\mathrm{Cd}$ (II) adsorption onto MC, adsorption tests were conducted in a different value of $\mathrm{pH}(2-6)$; the results are shown in Figure 9. At acidic $\mathrm{pH}$ the adsorption efficiency is too low, which can be explained by the competition between metal ions and hydronium $\mathrm{H}_{3} \mathrm{O}^{+}$ions present in the acid solution; hydronium ions are more adsorbed than metal ions due to their high mobility. At a slightly acidic $\mathrm{pH}$ (from 4 to 6), adsorption is more pronounced, and the adsorption efficiency increases with increasing $\mathrm{pH}$. The mechanism involved at this $\mathrm{pH}$ range is an ion exchange that occurs between $\mathrm{Cd}(\mathrm{II})$ and the cations localized in the MC exchange sites (36). The almost total elimination of $\mathrm{Cd}(\mathrm{II})$ is obtained beyond $\mathrm{pH}=5$.

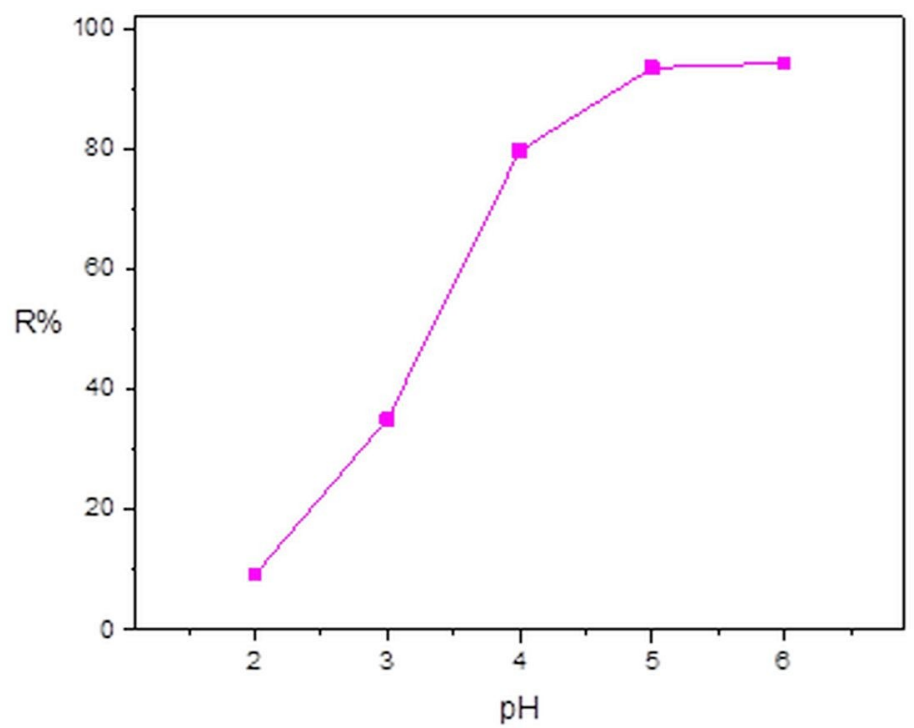

Figure 9: $\mathrm{pH}$ effect on $\mathrm{Cd}(\mathrm{II})$ adsorption onto $\mathrm{MC}$.

Temperature Effect

The temperature effect on MC adsorption capacity was studied. The experiments were conducted at various temperatures varied from $25^{\circ} \mathrm{C}$ to $55^{\circ} \mathrm{C}$. The amount of adsorbed cadmium ions increased with temperature (Figure 10), indicating an endothermic nature of adsorption. The rise in temperature leads to an increase in the adsorption capacity of MC clay. This increase may be due either to an increase in the MC available active sites or to an increase of the cadmium ions mobility in the solution (37). 


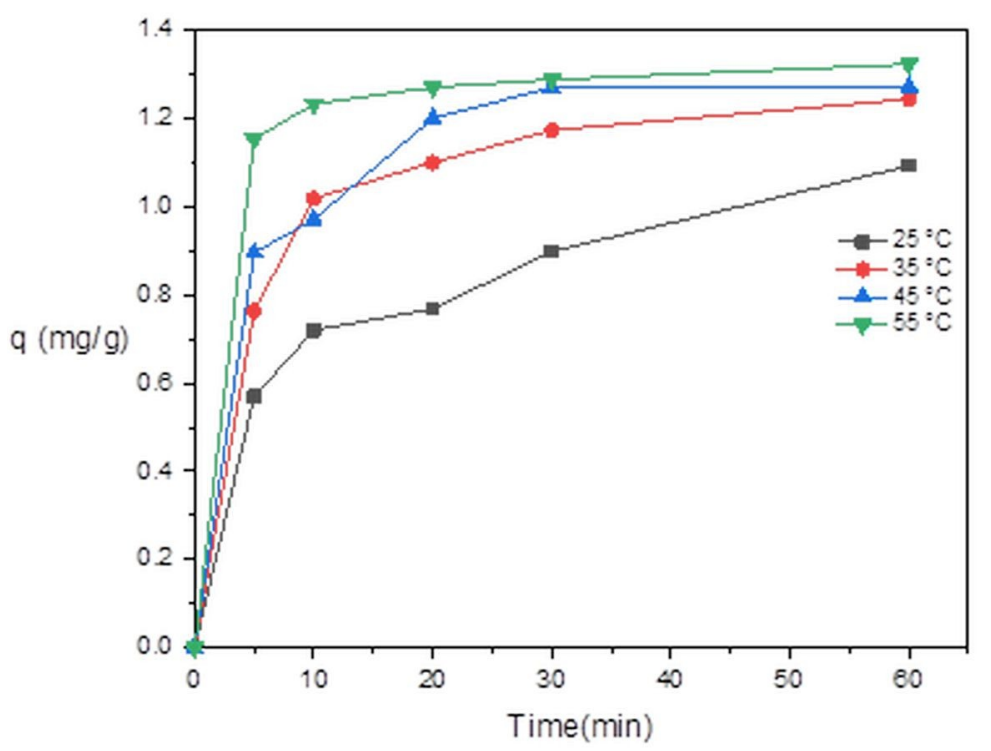

Figure 10: Temperature effect on the absorption capacity of MC.

\section{Adsorption Kinetics}

For the kinetic study of the adsorption process, the obtained experimental data were fitted by three kinetic models, pseudo-first-order, pseudo-secondorder, and Elovich, to describe the adsorption process.

The pseudo-first-order kinetic model expressed by Eq. (3) (38) :

$$
\log \left(q_{e}-q_{t}\right)=\log q_{e}-\frac{k_{1}}{2.303} t
$$

The pseudo-second-order equation is given by Eq. (4) (39) :

$$
\frac{t}{q_{t}}=\frac{1}{k_{2} q_{e}^{2}}+\frac{1}{q_{e}} t
$$

Where $\mathrm{q}_{\mathrm{e}}$ and $\mathrm{q}_{\mathrm{t}}$ are respectively the amounts of $\mathrm{Cd}$ (II) adsorbed on MC clay at equilibrium and at time $\mathrm{t}$ expressed in $(\mathrm{mg} / \mathrm{g}) . \mathrm{k}_{1}\left(\mathrm{~min}^{-1}\right)$ and $\mathrm{k}_{2}(\mathrm{~g} / \mathrm{mg}$ min) are the pseudo-first-order and pseudo-secondorder rate constants, respectively.

The Elovich kinetic model, describe chemisorption adsorption. Expressed by the equation (5) (40):

$$
\mathrm{q}_{\mathrm{t}}=\frac{1}{\beta} \ln (\alpha \beta)+\frac{1}{\beta} \ln \mathrm{t}
$$

Where a $\left(\mathrm{mg} \cdot \mathrm{g}^{-1} \cdot \mathrm{min}^{-1}\right)$ and $\beta \quad\left(\mathrm{g} \cdot \mathrm{mg}^{-1}\right)$ are respectively the initial adsorption rate and the desorption constant.

Table 2 summarizes the kinetic data.; the curves are shown in Figure 11. The pseudo-second-order model's obtained correlation coefficients are superior to those of pseudo-first-order and Elovich models. Also, the calculated values of the adsorption capacities at equilibrium $q_{e}$, from the pseudo-second-order are closer to the experimental values. From these results, it can be concluded that the adsorption of $\mathrm{Cd}$ (II) on $\mathrm{MC}$ is based on $\mathrm{a}$ chemical reaction, involving an exchange of electrons between the MC and the metallic solution $(41,42)$. 
Table 2: Kinetic parameters for Cd(II).

\begin{tabular}{|c|c|c|c|c|c|c|c|c|c|c|}
\hline \multirow{2}{*}{$\begin{array}{c}\text { Concentration } \\
(\mathrm{mg} / \mathrm{L})\end{array}$} & \multirow{2}{*}{$q_{e}(\exp )$} & \multicolumn{3}{|c|}{ pseudo-first-order } & \multicolumn{3}{|c|}{ pseudo-second-order } & \multicolumn{3}{|c|}{ Elovich } \\
\hline & & $q_{e}(\mathrm{cal})$ & $\mathbf{K}_{\mathbf{1}}$ & $\mathbf{R}_{1}{ }^{2}$ & $q_{e}(\mathrm{cal})$ & $\mathbf{K}_{2}$ & $\mathbf{R}^{2}$ & $\mathbf{a}$ & $\boldsymbol{\beta}$ & $\mathbf{R E}^{2}$ \\
\hline 10 & 1.10 & 0.75 & 0.0539 & 0.9444 & 1.14 & 0.1371 & 0.9989 & 1.3862 & 6.3572 & 0.9352 \\
\hline 40 & 3.45 & 1.63 & 0.0239 & 0.7992 & 3.54 & 0.0456 & 0.9995 & 4.1336 & 2.0121 & 0.8878 \\
\hline 60 & 4.09 & 0.78 & 0.0387 & 0.6750 & 4.14 & 0.1301 & 0.9995 & 157.4839 & 2.5336 & 0.4992 \\
\hline 80 & 4.37 & 0.85 & 0.0366 & 0.7933 & 4.39 & 0.1981 & 0.9999 & $2.83 E+10$ & 7.0824 & 0.9576 \\
\hline 100 & 4.93 & 1.53 & 0.0190 & 0.6284 & 4.96 & 0.0578 & 0.9991 & 2017.6545 & 2.7966 & 0.9016 \\
\hline 150 & 4.92 & 2.01 & 0.0211 & 0.7619 & 5.00 & 0.0394 & 0.9992 & 30.1701 & 1.8206 & 0.8643 \\
\hline 200 & 5.12 & 1.88 & 0.0275 & 0.8306 & 5.19 & 0.0501 & 0.9989 & $1.43 E+04$ & 3.1313 & 0.9530 \\
\hline
\end{tabular}
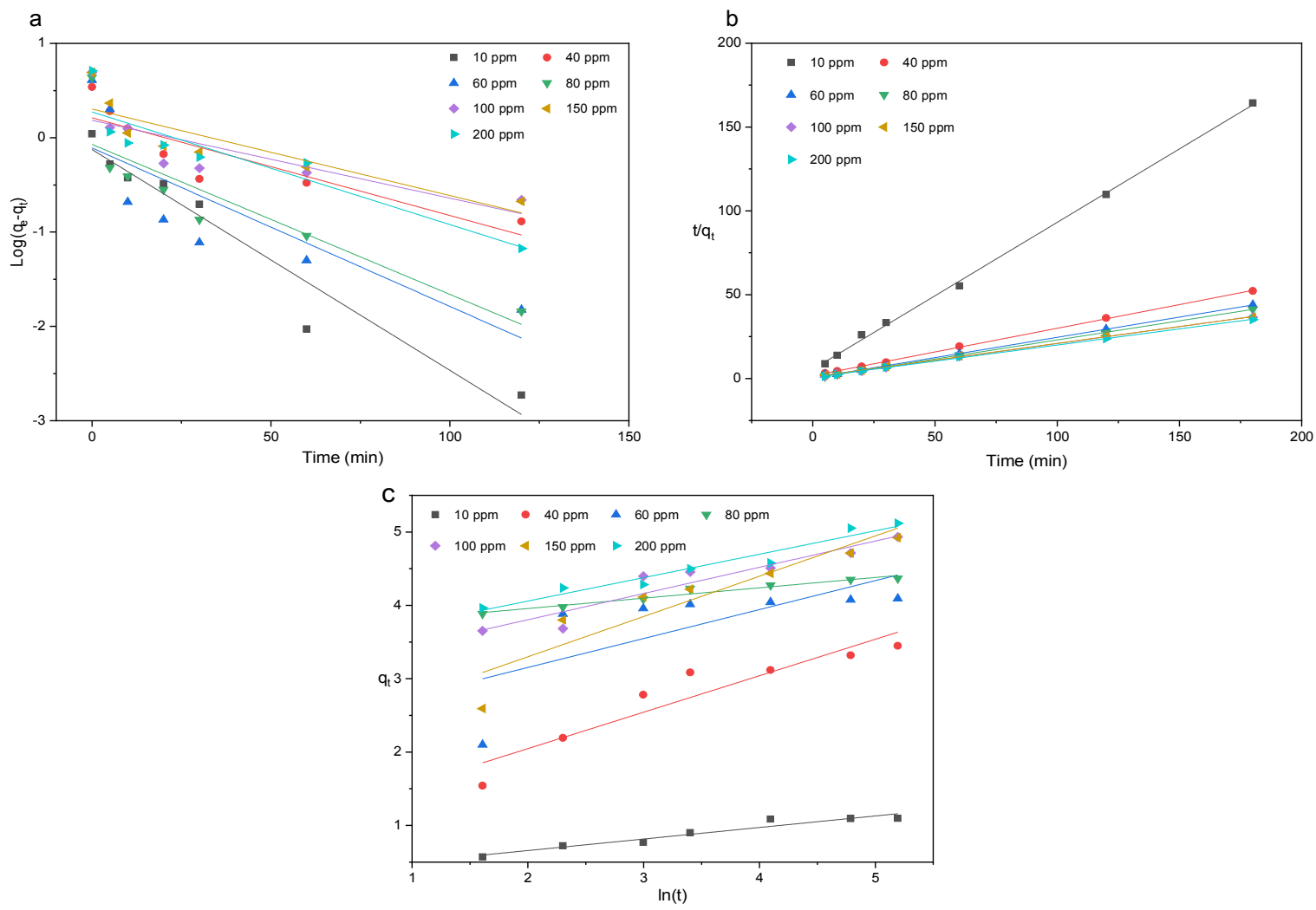

Figure 11: Kinetic models: Pseudo-first order (a), Pseudo-second order (b) and Elovich (c).

\section{Adsorption isotherms}

To understand the mechanisms that take place during the adsorption of $\mathrm{Cd}(\mathrm{II})$ onto $\mathrm{MC}$ and estimating MC adsorption capacity, three isotherm models are used, the Langmuir, Freundlich, and Temkin models.

The Langmuir isotherm model assumes monolayer coverage of a defined adsorption site without any interactions between the adsorbed ions (43).

The following equation gives Langmuir linear form:

$$
\frac{C_{e}}{q_{e}}=\frac{1}{K_{L} q_{m}}+\frac{C_{e}}{q_{m}}
$$

Where: $q_{m}$ : maximum adsorbed capacity $(\mathrm{mg} / \mathrm{g})$, $\mathrm{K}_{\mathrm{L}}(\mathrm{L} / \mathrm{mg})$ : equilibrium constant characteristic of the adsorbent, $\mathrm{C}_{\mathrm{e}}(\mathrm{mg} / \mathrm{L})$ : adsorbate concentration at equilibrium.

The separation factor constant $R_{L}$ is an essential characteristic used to ascertain the Langmuir isotherm model, which is defined by (44): 


$$
R_{L}=\frac{1}{\left(1+K_{L} C_{0}\right)}
$$

Where $\mathrm{C}_{0}(\mathrm{mg} / \mathrm{L})$ is the initial concentration and $\mathrm{K}(\mathrm{L} / \mathrm{mg})$ is the Langmuir constant.

Depending on the separation factor constant values, the adsorption is favorable if $0<R_{L}<1$, unfavorable if $R_{L}>1$, irreversible if $R_{L}=0$ or linear if $R_{L}=1$

The Freundlich isotherm model assumes that the adsorption processes occur on heterogeneous surfaces with a non-uniform energy distribution of adsorption sites on the surface. The Freundlich model admits the existence of interactions between the adsorbed molecules (45).

The following equation gives Freundlich linear equation:

$$
\log q_{e}=\log K_{F}+\frac{1}{n} \log C_{e}
$$

Where $\mathrm{K}_{\mathrm{F}}$ adsorption capacity, $\mathrm{n}$ : the adsorption intensity, $\mathrm{q}_{\mathrm{e}}$ : adsorption capacity at equilibrium $(\mathrm{mg} / \mathrm{g})$, and Ce: the solute concentration at equilibrium ( $\mathrm{mg} / \mathrm{L})$.

The Temkin isotherm assumes that sorption's free energy is a function of the surface coverage. The linear form is written as follows (46) :

$$
q_{e}=\frac{R T}{b_{T}} \ln K_{T}+\frac{\mathrm{RT}}{b_{T}} \ln C_{e}
$$

Where $\mathrm{T}$ : temperature $(\mathrm{K}), \mathrm{R}$ : universal gas constant $\left(8.314 \mathrm{~J} \cdot \mathrm{mol}^{-1} \cdot \mathrm{K}^{-1}\right), \mathrm{b}_{\mathrm{T}}(\mathrm{J} / \mathrm{mol})$ : heat of adsorption constant, and $\mathrm{K}_{\mathrm{T}}(\mathrm{L} / \mathrm{min})$ : equilibrium binding constant.

The calculated parameters of the adsorption isotherms with their correlation coefficients are reported in Table 3, and the curves are shown in Figure 12. According to the correlation coefficients, the Langmuir model is the most representative of the adsorption mechanism with correlation coefficients close to unity $\left(R^{2}=0.9981\right)$. Overall, it seems that the adsorption of metal cations is done by monolayer on identical sites of energy. This result showed that the heavy metal cations are homogeneously adsorbed through ionic adsorption assured by the negatively charged surface of MC.

Table 3: Isothermal parameters for Cd(II).

\begin{tabular}{llllllllllll}
\hline & \multicolumn{3}{c}{ Langmuir } & \multicolumn{4}{c}{ Freundlich } & \multicolumn{3}{c}{ Temkin } \\
\hline $\mathbf{q}_{\mathbf{e}(\mathbf{e x p})}$ & $\mathbf{q}_{\mathbf{m}, \text { cal }}$ & $\mathbf{K} \mathbf{L}$ & $\mathbf{R}^{\mathbf{2}}$ & $\mathbf{K}_{\mathbf{F}}$ & $\mathbf{1} / \mathbf{n}$ & $\mathbf{R}^{\mathbf{2}}$ & $\mathbf{K}_{\mathbf{T}}$ & $\mathbf{b}_{\mathbf{T}}(\mathbf{J} / \mathbf{m o l})$ & $\mathbf{B}$ & $\mathbf{R}^{\mathbf{2}}$ \\
\hline 5.12 & 5.25 & 0.1741 & 0.9981 & 1.4797 & 0.2758 & 0.9501 & 0.2006 & 1817.1277 & 1.3635 & 0.9850 \\
\hline
\end{tabular}



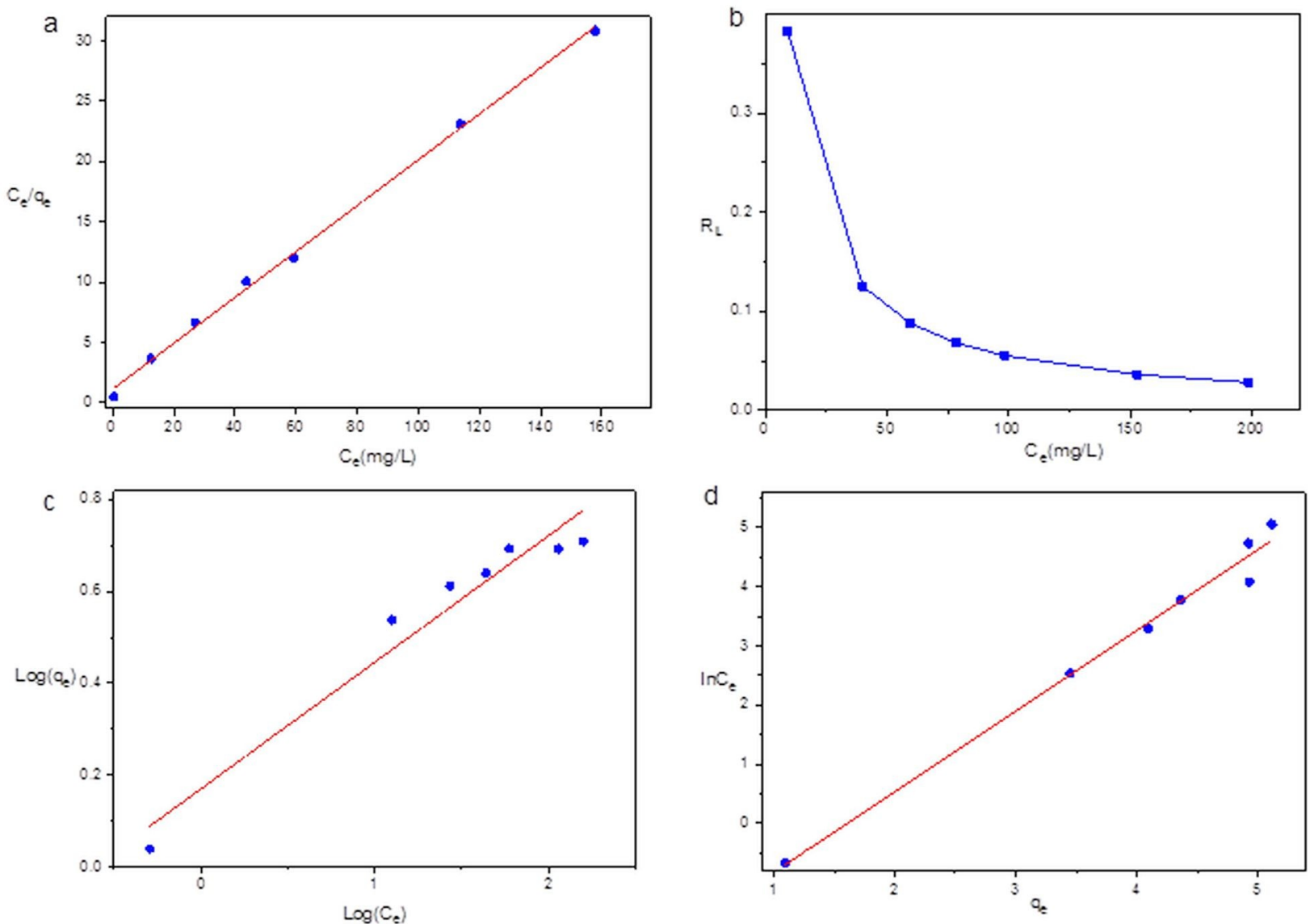

Figure 12 : Adsorption isotherms: Langmuir (a), Separation factor $R_{L}(b)$, Freundlich (c) and Temkin (d).

The $R_{L}$ values of different concentrations are tabulated in Table 4. All values are less than unity, implying that the Langmuir isotherm best describes heavy metal cations adsorption on MC (47).
Freundlich and Temkin's models are not suitable for modeling the metal cations' adsorption on the studied adsorbent.

Table 4: Separation factor $R_{L}$ of the Langmuir isotherm.

\begin{tabular}{clllllll}
\hline Concentration (mg/L) & $\mathbf{1 0}$ & $\mathbf{4 0}$ & $\mathbf{6 0}$ & $\mathbf{8 0}$ & $\mathbf{1 0 0}$ & $\mathbf{1 5 0}$ & $\mathbf{2 0 0}$ \\
\hline $\mathbf{R}_{\mathbf{L}}$ & 0.3825 & 0.1252 & 0.0876 & 0.0680 & 0.0550 & 0.0361 & 0.0281 \\
\hline
\end{tabular}

\section{Thermodynamic parameters}

To completely understand the adsorption nature and to describe thermodynamic behavior of the adsorption of $\mathrm{Cd}(\mathrm{II})$ onto $\mathrm{MC}$ clay, the free energy $(\Delta \mathrm{G})$, enthalpy $(\Delta \mathrm{H})$, and entropy $(\Delta S)$ were evaluated.

The equilibrium constant of adsorption $\mathrm{K}_{\mathrm{d}}$ is related to the free energy of the reaction $\Delta G\left(\mathrm{~J}^{\mathrm{mol}} \mathrm{m}^{-1}\right)$ and thus to the enthalpy $\Delta \mathrm{H}\left(\mathrm{J}_{\mathrm{mol}}^{-1}\right)$ and the entropy $\Delta \mathrm{S}\left(\mathrm{J} . \mathrm{mol}^{-1} \cdot \mathrm{K}^{-1}\right)$ of adsorption by the relation:

$$
\Delta G=\Delta H-T \Delta S=-R T \ln K_{d}
$$

It is therefore:

$$
\ln k_{d}=\frac{\Delta S}{R}-\frac{\Delta H}{R T}
$$

Where $\mathrm{K}_{\mathrm{d}}$ : equilibrium constant, $\mathrm{T}$ : temperature $(\mathrm{K})$, and $\mathrm{R}$ : universal gas constant $\left(8.314 \mathrm{~J} . \mathrm{mol}^{-1} \cdot \mathrm{K}^{-1}\right)$.

Figure 13 represents the plots of $\ln \left(K_{d}\right)$ as a function of $1 / T$. The slope and the intercept allow calculating respectively the standard variations of $\Delta \mathrm{H}, \Delta \mathrm{S}$ and $\Delta \mathrm{G}$. The obtained results are illustrated in Table 5 . 


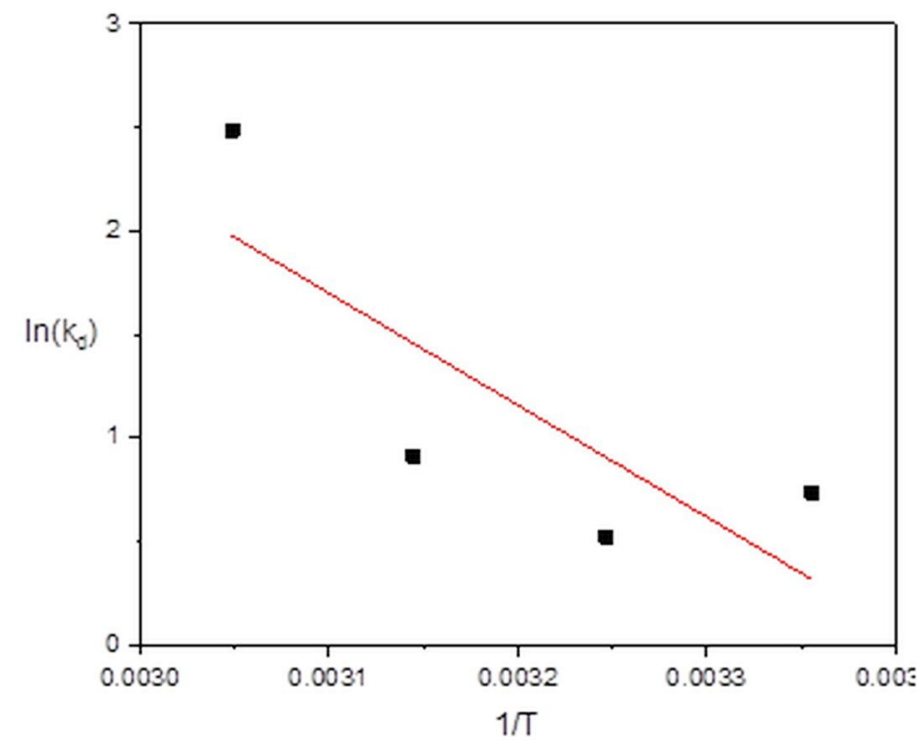

Figure 13: Representation of $\ln \left(K_{d}\right)$ as a function of $(1 / T)$.

The endothermic character of the adsorption process is confirmed by the positive values of $\Delta \mathrm{H}$, and as they are higher than $40 \mathrm{~kJ} / \mathrm{mol}$, it is, therefore, chemisorption (48). The spontaneous nature of the adsorption process is confirmed by the negative values of $\Delta G$. Positive values of $\Delta S$ evokes the increase of disorder at the solid/liquid interface during adsorption (49).

Table 5: Thermodynamic parameters.

\begin{tabular}{|c|c|c|c|c|}
\hline $\mathbf{T}(\mathbf{k})$ & $K_{d}(g / L)$ & $\Delta \mathrm{G}^{\circ}\left(\mathrm{KJ}^{\mathrm{mol}} \mathrm{mol}^{-1}\right)$ & $\Delta H^{\circ}\left(\mathrm{KJ} \mathrm{mol}^{-1}\right)$ & $\Delta \mathrm{S}^{\circ}\left(\mathrm{KJ} \cdot \mathrm{mol}^{-1} \cdot \mathrm{K}^{-1}\right)$ \\
\hline 298 & 2.08 & -1.82 & \multirow{4}{*}{44.97} & \multirow{4}{*}{0.15} \\
\hline 308 & 1.68 & -1.33 & & \\
\hline 318 & 2.49 & -2.41 & & \\
\hline 328 & 12.03 & -6.78 & & \\
\hline
\end{tabular}

\section{Mechanism of adsorption}

To understand the nature of interactions between the MC clay and the metal cations and to identify the different functional groups involved in this interaction, FTIR spectrophotometric analyses of the unloaded and the Cd-loaded clay were carried out. The FTIR spectrum is illustrated in Figure 14. The reduction in peak size at $3436 \mathrm{~cm}^{-1}$ and $1637 \mathrm{~cm}^{-1}$ indicates the hydroxyl group's involvement in the adsorbent-adsorbate interaction. Thus, the reduction of peaks attributed to the $\mathrm{Si}-\mathrm{O}$ and $\mathrm{Al}-\mathrm{Al}-\mathrm{OH}$ group indicates the involvement of the silanol and aluminol groups in the adsorption mechanism (50).
Possible mechanism (51):

$$
2 \mathrm{SO}^{-}+\mathrm{Cd}^{2+}-->(\mathrm{SO})_{2} \mathrm{Cd}
$$

With $\mathrm{S}=\mathrm{Si}$ or Al.

\section{Comparison with other adsorbents}

Table 6 shows a comparison of the maximum adsorption capacity $\left(q_{\max }\right)$ of $M C$ with different adsorbents reported in literature. As can be seen, the $\mathrm{q}_{\max }$ of $\mathrm{MC}$ for cadmium is higher compared with other adsorbent clay materials. Nevertheless, MC is promising adsorbent in the removal of cadmium ions from aqueous solutions considering of its low cost and its availability. 


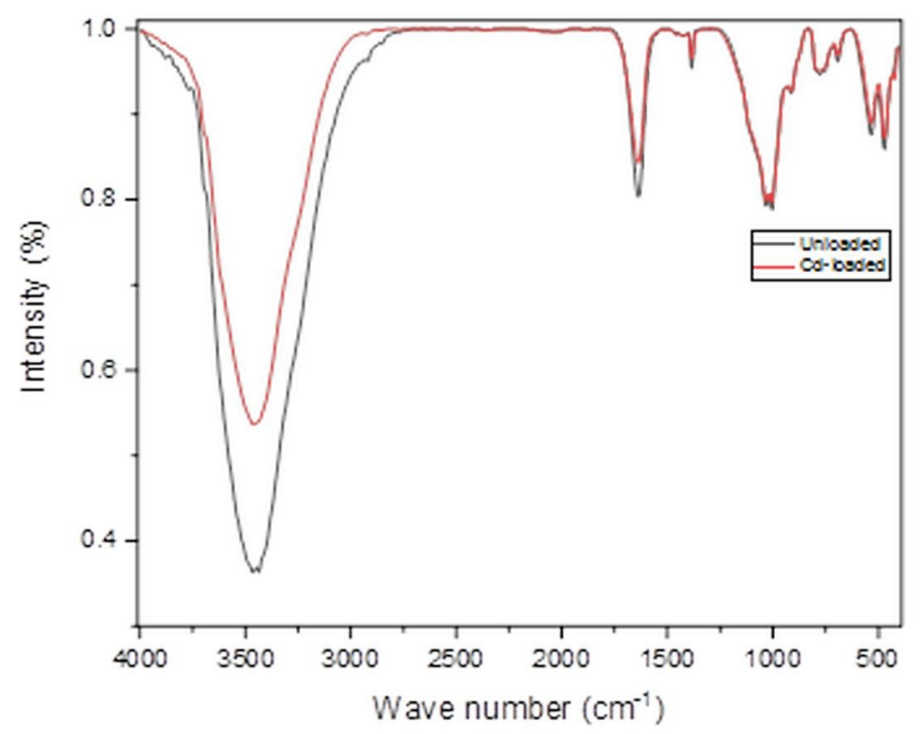

Figure 14: FTIR spectrum of MC before and after adsorption.

Table 6: Comparison of adsorption capacity of Cd(II) on different adsorbents.

\begin{tabular}{lcc}
\hline Adsorbent & $\mathbf{q}_{\mathbf{m a x}} \mathbf{( \mathbf { m g } \cdot \mathbf { g } ^ { - \mathbf { 1 } } \mathbf { ) }}$ & Reference \\
\hline Ball clay & 2.75 & $(52)$ \\
Kaolinite & 4.38 & $(53)$ \\
Palygorskite & 4.54 & $(54)$ \\
Kaolin & 3.04 & $(55)$ \\
Diatomite & 3.24 & $(55)$ \\
Kaolinite & 0.88 & $(56)$ \\
Moroccan Clay & 5.12 & This study \\
\hline
\end{tabular}

\section{CONCLUSION}

The results of this study indicate that MC, a low-cost adsorbent, can be very effective for cadmium removal from aqueous solution. The effect of different factors on adsorption was studied. The amount of $\mathrm{Cd}(\mathrm{II})$ adsorbed by MC increased with increasing $\mathrm{MC}$ dose, solution initial $\mathrm{pH}$, and contact time. The obtained kinetic values were well fitted by the pseudo-second-order thus proving that the process takes place as chemisorption.

Equilibrium data were also fitted by Langmuir isotherm, so the cadmium ions adsorb in monolayers and without any interactions between them. The maximum monolayer adsorption capacity for metal ions, using the Langmuir isotherm model equation, is equal to $5.25 \mathrm{mg} / \mathrm{g}$. The negative values of $\Delta G$ reveal the spontaneous nature during the adsorption process of metal ions onto $\mathrm{MC} . \Delta \mathrm{H}$ and $\Delta S$ positive values have proved the endothermic and randomness of the adsorption process. On the basis of these results, it can be concluded that natural clay (MC) can be used as an inexpensive and efficient adsorbent in the elimination of cadmium ions from wastewater.

\section{ACKNOWLEDGMENTS}

The authors are pleased to acknowledge Centre National de la Recherche Scientifique et Technique (CNRST) Morocco.

\section{REFERENCES}

1. Jiménez-Castañeda $M$, Medina D. Use of Surfactant-Modified Zeolites and Clays for the Removal of Heavy Metals from Water. Water. 2017 Mar 24;9(4):235. Doi:

https://doi.org/10.3390/w9040235.

2. Bouazza D, Miloudi H, Adjdir M, Tayeb A, Boos A. Competitive adsorption of $\mathrm{Cu}$ (II) and $\mathrm{Zn}$ (II) on impregnate raw Algerian bentonite and efficiency of extraction. Applied Clay Science. 2018 Jan;151:118-23. Doi: https://doi.org/10.1016/j.clay.2017.10.026.

3. Ezzeddine Z, Batonneau-Gener I, Pouilloux $Y$, Hamad H, Saad Z. Synthetic Nax Zeolite as a Very Efficient Heavy Metals Sorbent in Batch and Dynamic Conditions. Colloids and Interfaces. 2018 May $24 ; 2(2): 22$. Doi: https://doi.org/10.3390/colloids2020022. 
4. Essaadaoui Y, Lebkiri A, Rifi E, Kadiri L, Ouass A. Adsorption of lead by modified Eucalyptus camaldulensis barks: equilibrium, kinetic and thermodynamic studies. Dwt. 2018;111:267-77. Doi: https://doi.org/10.5004/dwt.2018.22191.

5. Zhang R, Zhou L, Zhang F, Ding Y, Gao J, Chen J, et al. Heavy metal pollution and assessment in the tidal flat sediments of Haizhou Bay, China. Marine Pollution Bulletin. 2013 Sep;74(1):403-12. Doi: https://doi.org/10.1016/j.marpolbul.2013.06.019.

6. Bensalah J, Habsaoui A, Abbou B, Kadiri L, Lebkiri I, Lebkiri $A$, et al. Adsorption of the anionic dye methyl orange on used artificial zeolites: kinetic study and modeling of experimental data. MediterrJChem, 2019 Nov 18;9(4):311-6. Doi: https://doi.org/10.13171/mjc941911181112jb.

7. Fu F, Wang Q. Removal of heavy metal ions from wastewaters: A review. Journal of Environmental Management. 2011 Mar;92(3):407-18. Doi: https://doi.org/10.1016/j.jenvman.2010.11.011.

8. Gupta VK, Mittal A, Gajbe V, Mittal J. Removal and Recovery of the Hazardous Azo Dye Acid Orange 7 through Adsorption over Waste Materials: Bottom Ash and De-Oiled Soya. Ind Eng Chem Res. 2006 Feb;45(4):1446-53. Doi:

https://doi.org/10.1021/ie051111f.

9. Gupta VK, Carrott PJM, Ribeiro Carrott MML, Suhas. Low-Cost Adsorbents: Growing Approach to Wastewater Treatment-a Review. Critical Reviews in Environmental Science and Technology. 2009 Oct 9;39(10):783-842. Doi:

https://doi.org/10.1080/10643380801977610.

10. Kabdaşlı I, Arslan T, Ölmez-Hancı T, ArslanAlaton I, Tünay O. Complexing agent and heavy metal removals from metal plating effluent by electrocoagulation with stainless steel electrodes. Journal of Hazardous Materials. 2009 Jun 15;165(13):838-45. Doi:

https://doi.org/10.1016/j.jhazmat.2008.10.065.

11. Ouallal H, Dehmani $Y$, Moussout H, Messaoudi L, Azrour M. Kinetic, isotherm and mechanism investigations of the removal of phenols from water by raw and calcined clays. Heliyon. 2019

May;5(5):e01616. Doi:

https://doi.org/10.1016/j.heliyon.2019.e01616.

12. Huisman JL, Schouten G, Schultz C. Biologically produced sulphide for purification of process streams, effluent treatment and recovery of metals in the metal and mining industry. Hydrometallurgy. 2006 Sep;83(1-4):106-13. Doi:

https://doi.org/10.1016/j.hydromet.2006.03.017.
13. Wang L, Hung Y-T, Shammas N. Volume 3: Physicochemical Treatment Processes. In: Handbook of Environmental Engineering [Internet]. Totowa, NJ: Humana Press; 2005. p. 1-703. ISBN: 978-159259-820-5. Available from: https://www.springer.com/gp/book/978158829165 $\underline{3}$

14. Keng P-S, Lee $S-L$, Ha S-T, Hung $Y-T$, Ong S-T. Removal of hazardous heavy metals from aqueous environment by low-cost adsorption materials. Environ Chem Lett. 2014 Mar;12(1):15-25. Doi: https://doi.org/10.1007/s10311-013-0427-1.

15. Kadiri L, Lebkiri A, Rifi EH, Ouass A, Essaadaoui $Y$, Lebkiri I. Mathematical modeling and thermodynamic study of copper (II) removal from aqueous solution by Coriandrum Sativum seeds. MediterrJChem,. 2019 Jan 20;7(6):478-90. Doi: https://doi.org/10.13171/mjc7619012111lk.

16. Essebaai H, Ismi I, Lebkiri A, Marzak S, Rifi EH. Kinetic and Thermodynamic Study of Adsorption of Copper (II) Ion on Moroccan Clay. Mediterr J Chem. 2019 Sep 13;9(2):102-15. Doi: https://doi.org/10.13171/mjc92190909510he.

17. Uddin MK. A review on the adsorption of heavy metals by clay minerals, with special focus on the past decade. Chemical Engineering Journal. 2017 Jan;308:438-62. Doi:

https://doi.org/10.1016/j.cej.2016.09.029.

18. Abbou B, Lebkiri I, Ouaddari $H$, Kadiri L, Ouass A, Habsaoui A, et al. Removal of Cd(II), Cu(II), and $\mathrm{Pb}$ (II) by adsorption onto natural clay: a kinetic and thermodynamic study. Turk J Chem. 2021;45:36276. Doi: https://doi.org/10.3906/kim-2004-82.

19. Arbaoui F, Boucherit MN. Comparison of two Algerian bentonites: Physico-chemical and retention capacity study. Applied Clay Science. 2014 Apr;9192:6-11. Doi:

https://doi.org/10.1016/j.clay.2014.02.001.

20. Besq A, Malfoy C, Pantet A, Monnet P, Righi D. Physicochemical characterisation and flow properties of some bentonite muds. Applied Clay Science. 2003 Oct;23(5-6):275-86. Doi:

https://doi.org/10.1016/S0169-1317(03)00127-3.

21. Sadki H, Ziat K, Saidi M. Adsorption of dyes on activated local clay in aqueous solution. J Mater Environ Sci. 2014;5(1):2060-5.

22. Ouaddari H, Karim A, Achiou B, Saja S, Aaddane A, Bennazha J, et al. New low-cost ultrafiltration membrane made from purified natural clays for direct Red 80 dye removal. Journal of Environmental 
Chemical Engineering. 2019 Aug;7(4):103268. Doi: https://doi.org/10.1016/j.jece.2019.103268.

23. Essaadaoui Y, Lebkiri A, Rifi EH, Kadiri L, Ouass A. Adsorption of cobalt from aqueous solutions onto Bark of Eucalyptus. Mediterr J Chem. 2018 Sep 15;7(2):145-55. Doi:

https://doi.org/10.13171/mjc72/01808150945essaadaoui.

24. Ouaddari $H$, Beqqour D, Bennazha J, El Amrani I-E, Albizane A, Solhy A, et al. Natural Moroccan clays: Comparative study of their application as recyclable catalysts in Knoevenagel condensation. Sustainable Chemistry and Pharmacy. 2018 Dec; 10:1-8. Doi:

https://doi.org/10.1016/j.scp.2018.07.003.

25. Bedelean H, Măicăneanu A, Burcă S, Stanca M. Removal of heavy metal ions from wastewaters using natural clays. Clay miner. 2009

Dec;44(4):487-95. Doi:

https://doi.org/10.1180/claymin.2009.044.4.487.

26. Mobarak M, Selim AQ, Mohamed EA, Seliem MK. A superior adsorbent of $\mathrm{CTAB} / \mathrm{H}_{2} \mathrm{O}_{2}$ solution-modified organic carbon rich-clay for hexavalent chromium and methyl orange uptake from solutions. Journal of Molecular Liquids. 2018 Jun;259:384-97. Doi:

https://doi.org/10.1016/j.molliq.2018.02.014.

27. Adebowale KO, Olu-Owolabi BI, Chigbundu EC. Removal of Safranin-O from Aqueous Solution by Adsorption onto Kaolinite Clay. JEAS. 2014;04(03):89-104. Doi: https://doi.org/10.4236/jeas. 2014.43010.

28. Bentahar Y, Hurel C, Draoui K, Khairoun S, Marmier N. Adsorptive properties of Moroccan clays for the removal of arsenic(V) from aqueous solution. Applied Clay Science. 2016 Jan;119:385-92. Doi: https://doi.org/10.1016/j.clay.2015.11.008.

29. Chinoune K, Bentaleb K, Bouberka Z, Nadim A, Maschke $U$. Adsorption of reactive dyes from aqueous solution by dirty bentonite. Applied Clay Science. 2016 Apr;123:64-75. Doi: https://doi.org/10.1016/j.clay.2016.01.006.

30. Eloussaief M, Kallel N, Yaacoubi A, Benzina M. Mineralogical identification, spectroscopic characterization, and potential environmental use of natural clay materials on chromate removal from aqueous solutions. Chemical Engineering Journal. 2011 Apr;168(3):1024-31. Doi: https://doi.org/10.1016/j.cej.2011.01.077.

31. Gourouza M, Zanguina A, Natatou I, Boos A. Characterization of a mixed clay Niger. Revue
CAMES-Sciences et Structure de la Matière. 2013;1:29-39.

32. Madejová J, Pálková H. NIR Contribution to The Study of Modified Clay Minerals. In: Developments in Clay Science [Internet]. Elsevier; 2017 [cited 2021 May 12]. p. 447-81. Available from: https://linkinghub.elsevier.com/retrieve/pii/B97800 $\underline{81003558000138}$

33. Sing KSW, Everett DH, Haul RAW, Moscou L, Pierotti RA, Rouquerol J, et al. Reporting physisorption data for gas/solid systems with special reference to the determination of surface area and porosity (Recommendations 1984). Pure Appl Chem. 1985 Jan 1;57(4):603-19. Doi:

https://doi.org/10.1351/pac198557040603.

34. Gopal Reddi MR, Gomathi T, Saranya M, Sudha PN. Adsorption and kinetic studies on the removal of chromium and copper onto Chitosan-g-maliec anhydride-g-ethylene dimethacrylate. International Journal of Biological Macromolecules. 2017 Nov; 104:1578-85. Doi: https://doi.org/10.1016/j.ijbiomac.2017.01.142.

35. Dincer A, Gunes Y, Karakaya N, Gunes E.

Comparison of activated carbon and bottom ash for removal of reactive dye from aqueous solution. Bioresource Technology. 2007 Mar;98(4):834-9. Doi:

https://doi.org/10.1016/j.biortech.2006.03.009.

36. Kaya A, Ören AH. Adsorption of zinc from aqueous solutions to bentonite. Journal of Hazardous Materials. 2005 Oct;125(1-3):183-9. Doi:

https://doi.org/10.1016/j.jhazmat.2005.05.027.

37. Ozdes D, Duran C, Senturk HB. Adsorptive removal of $\mathrm{Cd}$ (II) and $\mathrm{Pb}$ (II) ions from aqueous solutions by using Turkish illitic clay. Journal of Environmental Management. 2011

Dec;92(12):3082-90. Doi:

https://doi.org/10.1016/j.jenvman.2011.07.022.

38. Lagrergen S. Zur theorie der sogenannten adsorption gelöster stoffe kungliga svenska vetenskapsakademiens. Handlingar. 1898;24(4):139.

39. Gurses A, Dogar C, Yalcin M, Acikyildiz M, Bayrak R, Karaca $S$. The adsorption kinetics of the cationic dye, methylene blue, onto clay. Journal of Hazardous Materials. 2006 Apr 17;131(1-3):21728. Doi:

https://doi.org/10.1016/j.jhazmat.2005.09.036.

40. Gupta S, Babu BV. Removal of toxic metal $\mathrm{Cr}(\mathrm{VI})$ from aqueous solutions using sawdust as 
adsorbent: Equilibrium, kinetics and regeneration studies. Chemical Engineering Journal. 2009 Aug $1 ; 150(2-3): 352-65$. Doi: https://doi.org/10.1016/j.cej.2009.01.013.

41. Abbas M, Kaddour S, Trari M. Kinetic and equilibrium studies of cobalt adsorption on apricot stone activated carbon. Journal of Industrial and Engineering Chemistry. 2014 May;20(3):745-51. Doi: https://doi.org/10.1016/j.jiec.2013.06.030.

42. Saeed $A$, Sharif $M$, Iqbal M. Application potential of grapefruit peel as dye sorbent: Kinetics, equilibrium and mechanism of crystal violet adsorption. Journal of Hazardous Materials. 2010 Jul;179(1-3):564-72. Doi: https://doi.org/10.1016/j.jhazmat.2010.03.041.

43. Langmuir I. The Adsorption of Gases on Plane Surfaces of Glass, Mica And Platinum. J Am Chem Soc. 1918 Sep;40(9):1361-403. Doi: https://doi.org/10.1021/ja02242a004.

44. Obayomi KS, Auta M. Development of microporous activated Aloji clay for adsorption of lead (II) ions from aqueous solution. Heliyon. 2019 Nov; 5(11):e02799. Doi: https://doi.org/10.1016/j.heliyon.2019.e02799.

45. Freundlich $\mathrm{H}$. Über die Adsorption in Lösungen. Zeitschrift für Physikalische Chemie [Internet]. 1907 Jan 1 [cited 2021 May 12];57U(1). Available from: https://www.degruyter.com/document/doi/10.1515/ zpch-1907-5723/html.

46. Tempkin M, Pyzhev V. Kinetics of ammonia synthesis on promoted iron catalyst. Acta Phys Chim USSR. $1940 ; 12(1): 327$.

47. Ouass $A$, Ismi I, Elaidi $H$, Lebkiri $A$, Cherkaoui M, Rifi EH. Mathematical Modeling Of The Adsorption Of Trivalent Chromium By The Sodium Polyacrylate Beads. J Mater Environ Sci. 2017;8(10):3448-56. URL:

https://www.jmaterenvironsci.com/Document/vol8/ vol8 N10/363-JMES-2585-Ouass.pdf.

48. Benguella B, Yacouta-Nour A. Elimination des colorants acides en solution aqueuse par la bentonite et le kaolin. Comptes Rendus Chimie. 2009 Jun;12(6-7):762-71. Doi: https://doi.org/10.1016/j.crci.2008.11.008.
49. Lebkiri I, Abbou B, Kadiri L, Ouass A, Essaadaoui $Y$, Habssaoui $A$, et al. Removal of methylene blue dye from aqueous solution using a superabsorbant hydrogel the polyacrylamide: isotherms and kinetic studies. Mediterr J Chem. 2019 Nov 25;9(5):337-46. Doi: https://doi.org/10.13171/mjc941911251089il.

50. Qiu W, Zheng Y. Removal of lead, copper, nickel, cobalt, and zinc from water by a cancrinitetype zeolite synthesized from fly ash. Chemical Engineering Journal. 2009 Jan;145(3):483-8. Doi: https://doi.org/10.1016/j.cej.2008.05.001.

51. Yavuz Ö, Altunkaynak Y, Güzel F. Removal of copper, nickel, cobalt and manganese from aqueous solution by kaolinite. Water Research. 2003

Feb;37(4):948-52. Doi:

https://doi.org/10.1016/S0043-1354(02)00409-8.

52. Rao RAK, Kashifuddin M. Adsorption studies of Cd(II) on ball clay: Comparison with other natural clays. Arabian Journal of Chemistry. 2016

Nov; 9:S1233-41. Doi:

https://doi.org/10.1016/j.arabjc.2012.01.010.

53. Unuabonah EI, Adebowale KO, Olu-Owolabi BI, Yang LZ. Comparison of sorption of $\mathrm{Pb}^{2+}$ and $\mathrm{Cd}^{2+}$ on Kaolinite clay and polyvinyl alcohol-modified Kaolinite clay. Adsorption. 2008 Dec;14(6):791803. Doi: https://doi.org/10.1007/s10450-0089142-9.

54. Alvarez-Ayuso E, Garcia-Sanchez A. Removal of cadmium from aqueous solutions by palygorskite. Journal of Hazardous Materials. 2007 Aug 17;147(1-2):594-600. Doi: https://doi.org/10.1016/j.jhazmat.2007.01.055.

55. Ulmanu M, Marañón $E$, Fernández $Y$, Castrillón L, Anger I, Dumitriu D. Removal of Copper and Cadmium Ions from Diluted Aqueous Solutions by Low Cost and Waste Material Adsorbents. Water, Air, and Soil Pollution. 2003;142(1/4):357-73. Doi: https://doi.org/10.1023/A:1022084721990.

56. Jiang $M$, Jin $X$, Lu X-Q, Chen Z. Adsorption of $\mathrm{Pb}(\mathrm{II}), \mathrm{Cd}(\mathrm{II}), \mathrm{Ni}(\mathrm{II})$ and $\mathrm{Cu}(\mathrm{II})$ onto natural kaolinite clay. Desalination. 2010 Mar;252(1-3):339. Doi:

https://doi.org/10.1016/j.desal.2009.11.005. 